$\underline{\text { Interview }}$

\title{
'I Express All my Joys, All my Pain through my Art': An Interview with Fifi Mukuna
}

\author{
Catherine $\mathrm{Mao}{ }^{1 *}$
}

Published: April 11, 2020

\section{INTRODUCTION}

Fifi Mukuna (born 1968, Kinshasa, Democratic Republic of the Congo) is a comics artist and caricaturist. Beginning in the 1990s, her work regularly appeared in both mainstream and satirical local press outlets. In 2002, she was forced to leave the country because of her political caricatures. She is now a political refugee, and lives and works in northern France.

Mukuna is a multi-faceted artist: political caricaturist, comics artist, graphic designer in advertising, educator, and cultural ambassador for the Alliance Francaise and the Red Cross. Her comics work has appeared in several anthologies (À l'Ombre du Baobab, Une Journée dans la Vie d'un Africain d'Afrique, Là-Bas... Na Poto), and her first solo graphic novel (Kisi le Collier) was published in 2013. This transcript comes from a telephone interview with her, with examples of her comics work.

Your work has appeared in lots of different contexts; maybe we could talk a little about your journey in comics so far. How did you become a comics artist?

Comics were my passion from a very young age. I grew up in Kinshasa where bande dessinée is very popular; not surprising, given the Belgian colonial presence in the past. I also spent part of my childhood in Brussels, where my interest in comics developed further. Even when I was a child, I loved telling stories with images. My big sister paid a lot of attention to my drawing and started writing stories for me to illustrate. I used to copy the style of other artists and famous characters, like Bob et Bobette by the Belgian artist Willy Vandersteen. ${ }^{1}$ I loved that series! I used to copy out whole pages from it.

\section{Did you already want to make comics your career?}

Yes! First of all, I trained in Liberal Arts in the Democratic Republic of Congo (DRC). Then, at the end of the 1980s, I enrolled in fine arts at the Académie des Beaux-Arts (ABA) in Kinshasa. I was interested in a course there, run by the late Mongo Cissé. He was famous for his comics characters Pili-Pili and Mata-Mata. Before studying with him, I had already read a few of his comics; I loved his humour and especially his drawing style. His lines were really well defined and he used flat colours. He'd worked in Hergé's workshops, and developed a style which was very similar to Hergés clear line, with the same qualities of simplicity and readability. Mongo Cissé inspired me a lot, and I enrolled at ABA because I wanted to take his course. It was the right decision. He encouraged me to make comics and to find my own style of drawing, inspired by clear line.

\section{Were you influenced by any other artists at all? Did any female artists influence your work?}

No, unfortunately not. I can't say that any woman has influenced my work particularly. When I started drawing, female comics artists just didn't exist in Africa. Only later did I discover the work of some French artists, like Florence Cestac and Isabelle Dethan. These women inspire me a lot, both in their drawing style and their use of

${ }^{1}$ Translator's note: This series (Suske en Wiske in the original Flemish) has been translated into English variously as Spike and Suzy and Willy and Wanda, and is also known as Luke and Lucy in video game and film adaptations. 
colour. But I've noticed that more and more women artists are getting noticed in Africa. I'm confident that soon emerging talent will be able to benefit from the influence of female artists. In terms of my other sources of inspiration, I must say that the artists that inspire my work the most are my friends and those around me, whether they live close by or very far away! Sometimes I have trouble with narrative or graphic aspects of my work, and it's often other comics creators who help me find the right solution. Barly Baruti, for example, has been there for me since the start of my career. ${ }^{2}$ He helped me choose my techniques, in working on my use of colour, to find my own style. And he's still doing it today! In spite of all his success, he's stayed humble and still spends time helping his friends. He's a good example of the type of person who inspires me.

Mongo Cissé, Barly Baruti...it's clear that comics is a prominent part of Congolese arts and culture.

Absolutely! The DRC has a rich narrative and graphic heritage. I've mentioned Mongo Cissé, but before him there were plenty other important creators. OK, they published their work in black and white, in fanzines and other little-known magazines, but Congolese people have loved art and humour for a long time. Comics are especially popular in newspapers. When I worked for them, newspapers would often ask me to do the back cover; they called it the buitieme: a whole page of caricatures covering all the news in the paper. People love it! The drawings are the first thing they look at when deciding to buy a newspaper.

Tell me about your experience working in journalism. You went to art school to do comics, but ended up doing caricature...

Oh, it came about really by accident. I was still studying at the ABA when I saw that a newspaper was looking for a caricaturist. I applied for the job. When I saw the boss's face, I realised that he was surprised a woman had applied! But I did well in the recruitment tests and they hired me. At that point I was in my final year of university, so for a year I studied as well as did my work in the newspaper. It was a really good experience for me. At the art school I encountered lots of new influences and reference points, and at the end of my studies I was trying to free myself of all those influences and find my own style. Working in newspapers, I got more efficient, I mastered my technique and developed my own style.

\section{How would you describe your style?}

I would call it semi-realist: a mixture of realism and humour. My style is based on the deformation of characters' features, not in an abstract or minimalist way, but staying grounded in realism. That's why I include a lot of humour, which in my mind is the common link between my caricatures and my comics.

\section{Do you use any techniques in particular?}

My favourite technique is 'direct colour', that is, applying colour directly onto the page. I do the sketches and the inking, then immediately add the colour. I prefer using liquid inks, which are like Indian inks, but runnier, more pigmented, and which give a bit of a different texture. I dilute them to get a watercolour effect. I stick to direct colour, even if it's a bit riskier. Sometimes other artists are surprised by my technique, and they try to warn me against it, saying that I could mess up the colour and end up losing my whole drawing. I must admit, sometimes I play it safe and photocopy the original art and then add the colour to the photocopy. But in general, I like taking the risk with direct colour. Colour is really important for me; it changes the tone of the art and has an important narrative function. For example, the story of my comic, Kisi le Collier, takes place entirely in a hairdresser's, a really feminine space. I wanted it to be really brightly coloured, warm and sparkling. It's very important for me that my use of colour has a function in my stories.

\section{What kind of stories do you want to tell?}

I take inspiration from the things I see around me. Often my friends and acquaintances will tell me about things they've been through, and even suggest that I make a comic out of their experiences. I'm happy that they're able to express themselves through my art. I don't want to tell the same old stories, things that other artists have already done before me. I want to avoid clichés and truisms, especially when it comes to Africa. People often present one, repetitive version of Africa: little exotic villages, poor children... I want to show Africa's other reality, the same reality that exists right here in Europe, the one I see every day. For example, in Kisi le Collier I talk about how some African immigrants in Europe are still very superstitious, and how that affects life in central Brussels.

2 Translator's note: Barly Baruti (1959-) is a renowned Congolese comics artist. 
Does this desire to tell untold stories come from your own experience? You were forced to leave your home country because of your caricatures, you've been directly affected by censorship and its consequences...

That's true. After I got my degree, I continued making caricatures for newspapers. I used a pseudonym, so no one knew I was a woman. The government didn't really like my work, but as long as my identity stayed secret, I didn't have any problems. Sadly, that didn't last. As soon as the government found out who I was and that I was a woman, my life was threatened. I had to leave the country quickly, leaving my young children behind. I went to France as a refugee, then I lost my husband who had stayed behind in Kinshasa. It's true that when you live through painful, difficult experiences, you want to talk about them, leave some evidence of them somewhere. Today, I'm lucky enough to be able to use comics as a means of talking about the real world, and to talk about things that are important to me. For example, I tell stories about forced marriage, female genital mutilation, the importance of vaccination, street kids... I think that comics is a great medium for educating people and raising awareness.

You say that art has helped you get through the hard times you've experienced. How so?

When I first arrived in France, I was very lonely. But I still had my art, or rather, art was all I had left. So I drew a lot, to express my emotions, to get things out. I was lucky and quickly made friends who supported me and encouraged me to continue drawing. Now I realise just how right they were. I express all my joys, all my pain through my art. For me it's a great means of expression. That's what I try to teach my students. When I arrived in northern France, I started doing comics workshops for a charity. What's important for me is giving kids the tools and the skills so they can express whatever they want. The end goal isn't creating professional artists, but enabling them to make up their own stories and their own characters. I love doing that sort of work, and the kids love it too. We do a lot of activities about illustrated stories, about dialogue...we've published several anthologies, supported by the regional council and community centres in Roubaix. ${ }^{3}$

What are you working on at the moment? Are there any publications in the pipeline?

Now more than ever, I want to talk about what I've been through. I'm working on an autobiographical comic which I'm going to self-publish. I'm conscious of the fact that I couldn't do it if I'd stayed in Kinshasa, because of the government, the current repression and censorship. For this project, I'm trying new techniques, new atmospheres. My style isn't fixed, it continues to evolve; it's always a work in progress...I'm trying colder colours, to describe more sombre things. And the colours are so different in all the towns I've lived in (Lille, Kinshasa, Brussels), depending on the season of the year...when I first came to Europe, for example, it was right in the middle of autumn. For me, it's crucial to be able to adapt, depending on the story I want to tell.

Telephone interview conducted on 27/10/2018

\section{TRANLATOR'S DETAILS}

Lise Tannahill works at the University of Glasgow, UK.

Email:1.tannahill.1@research.gla.ac.uk

\footnotetext{
${ }^{3}$ Translator's note: A town in the north of France, near the Belgian border.
} 


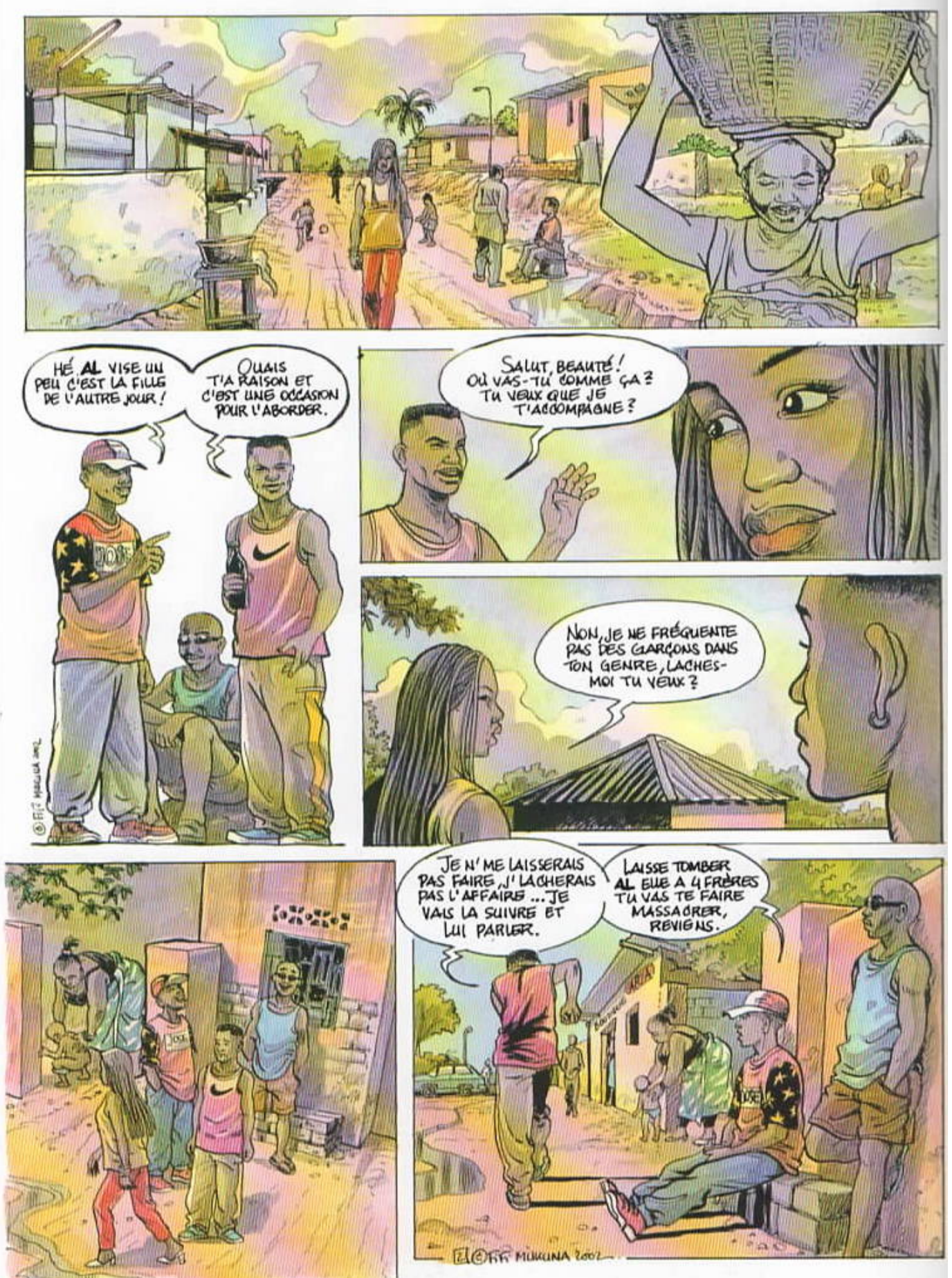



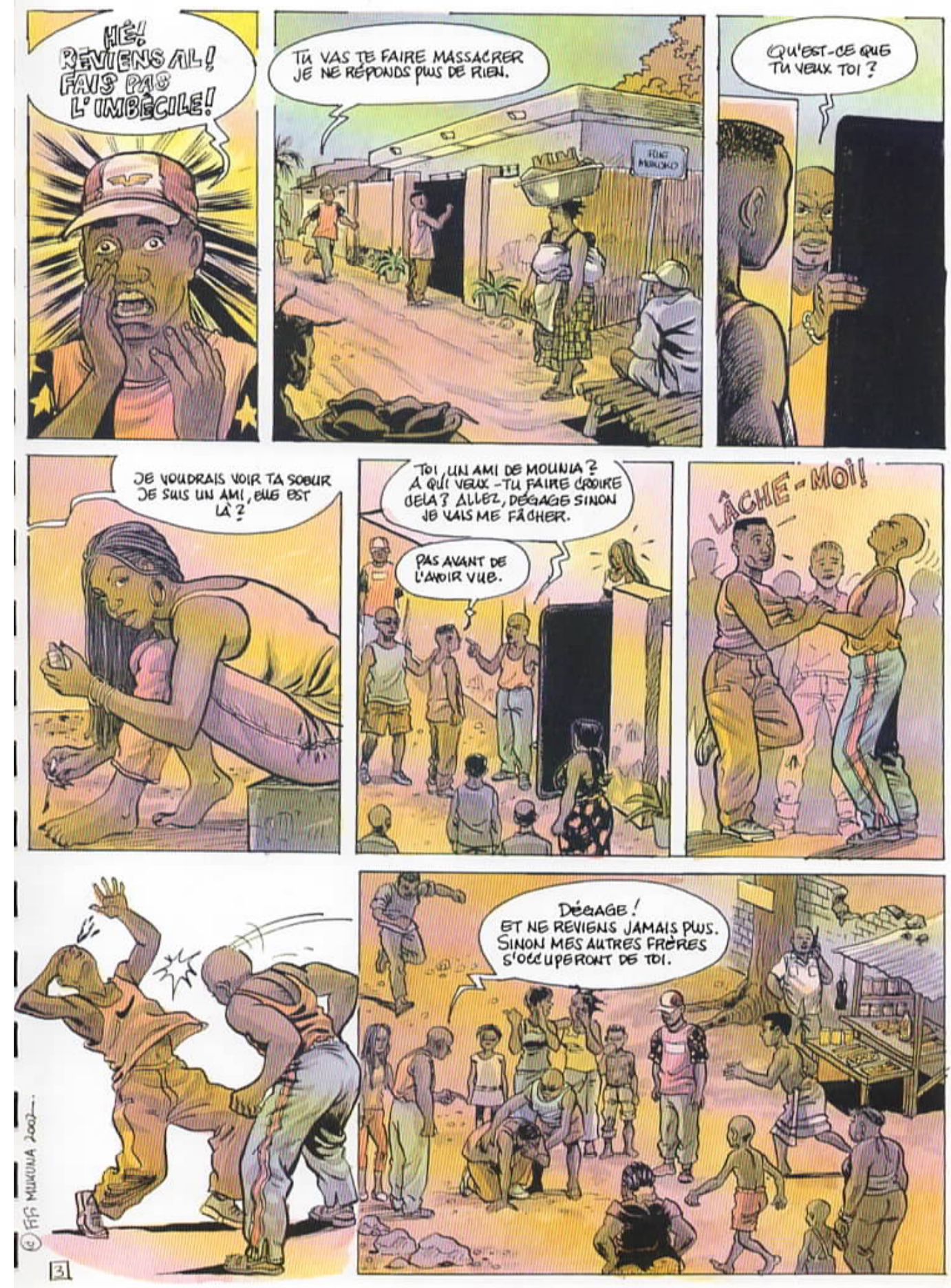

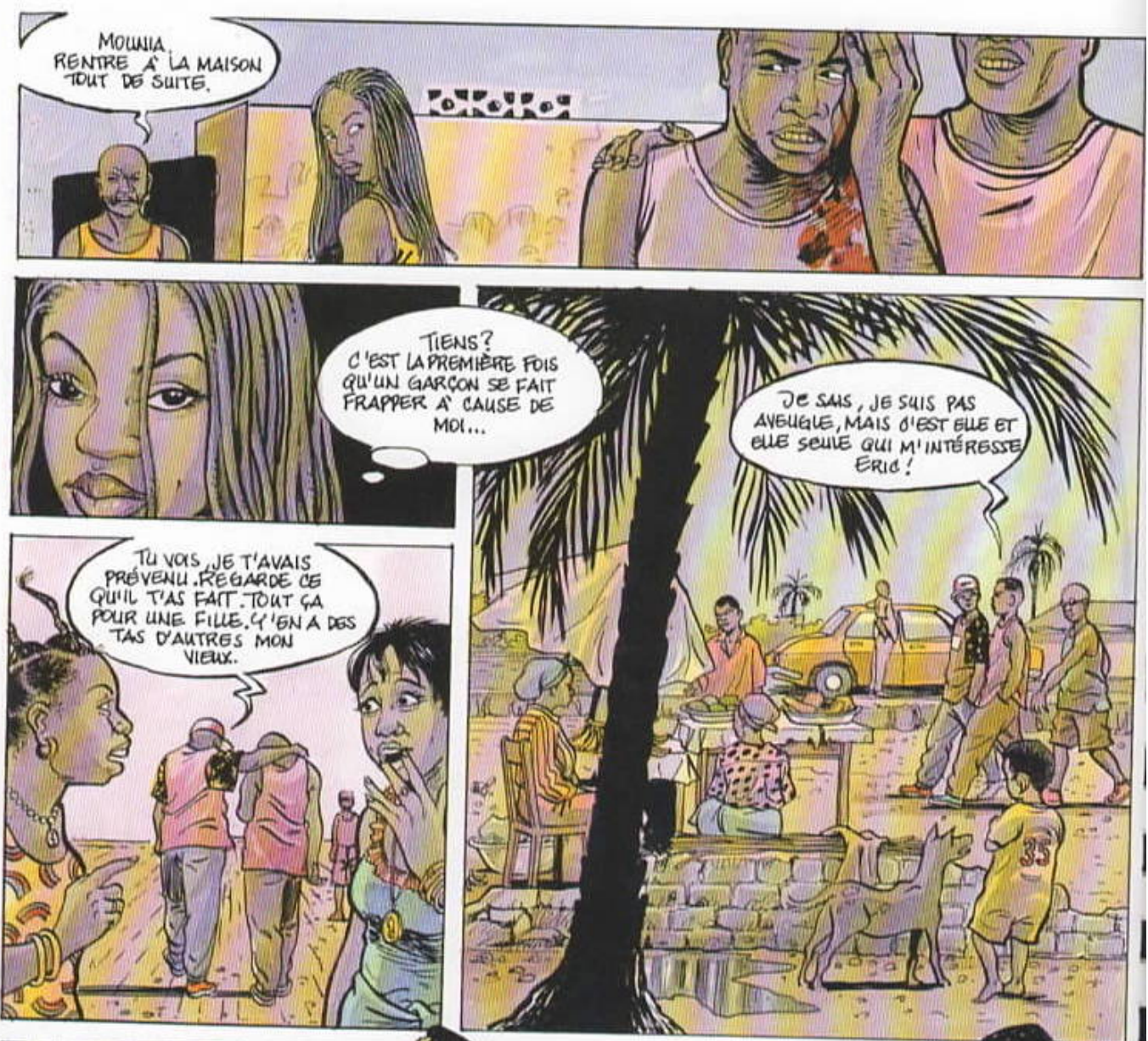

REMIÉRE FOIS A' CAUSE DE Mol...
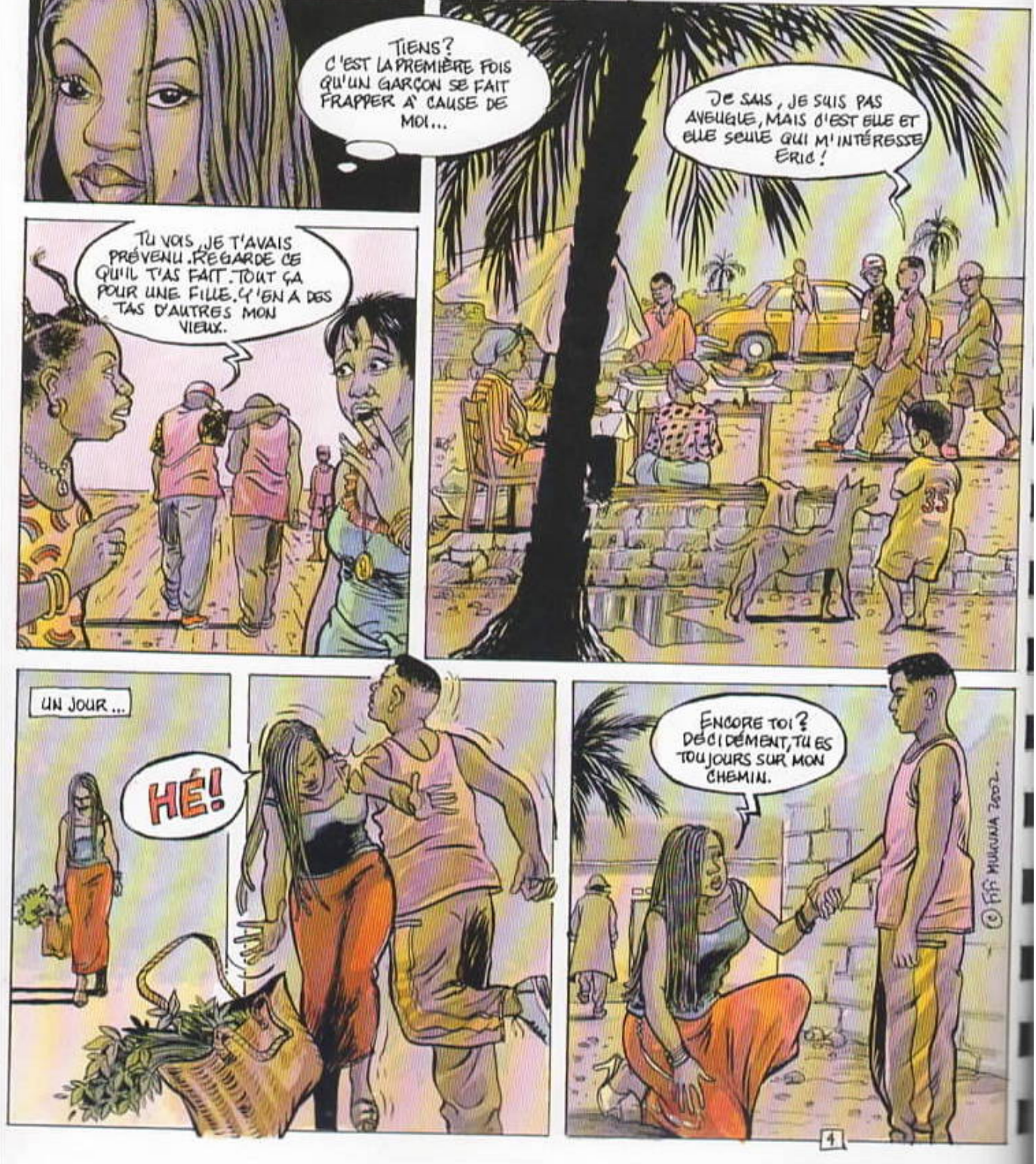

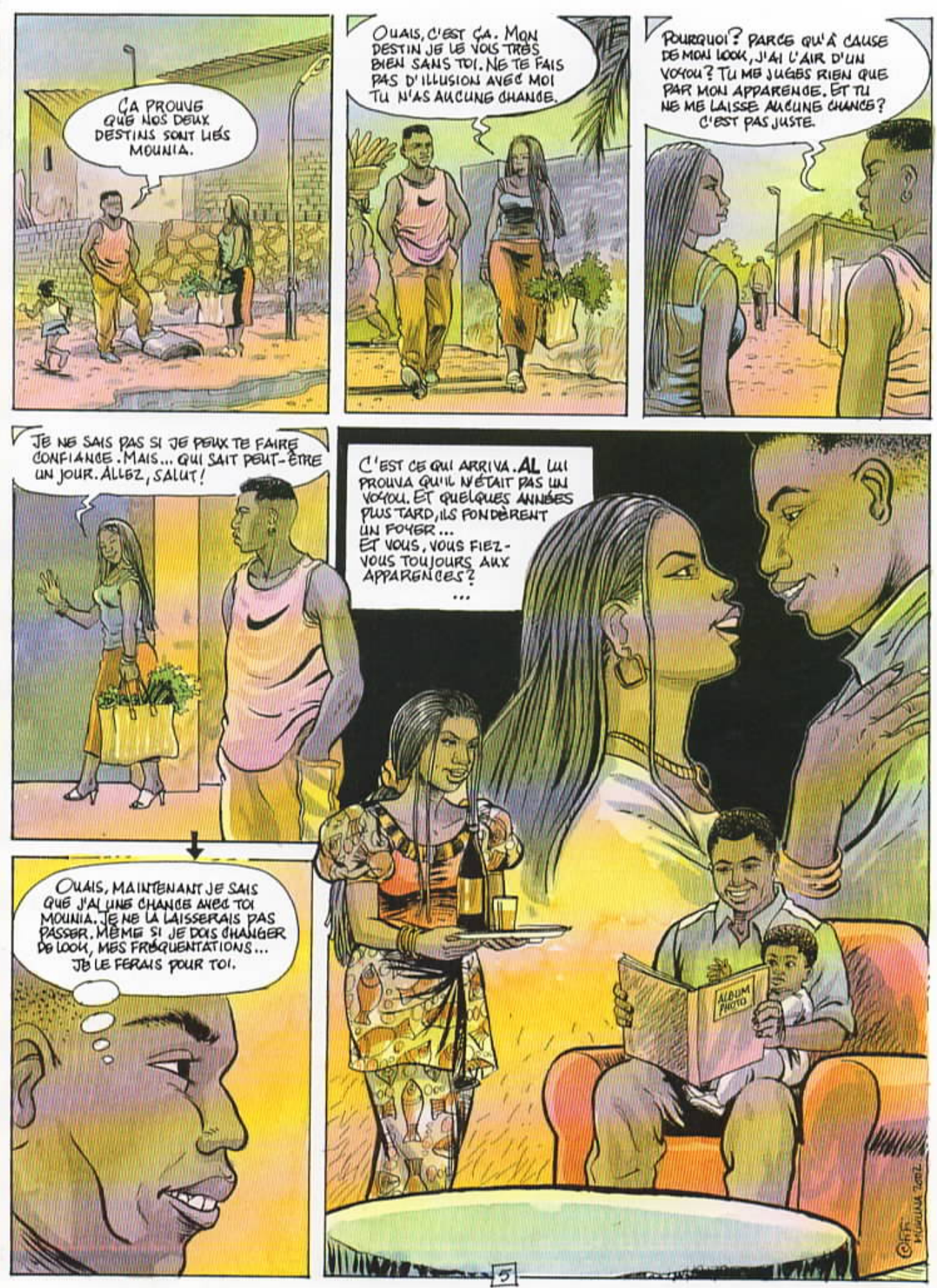

Citation: Mao, C. (2020). 'I Express All my Joys, All my Pain through my Art’: An Interview with Fifi Mukuna (L. Tannahill, Trans.). Feminist Encounters: A Journal of Critical Studies in Culture and Politics, 4(1), 10. https://doi.org/10.20897/femenc/7914

Copyright (C) 2020 by Author/s and Licensed by Lectito BV, Netherlands. This is an open access article distributed under the Creative Commons Attribution License which permits unrestricted use, distribution, and reproduction in any medium, provided the original work is properly cited. 